\title{
SYNAPSES IN THE RAT AND PIGEON MEDIAN EMINENCES*
}

\section{To the Editors:}

It has been established that the median eminence of the hypothalamus is the neurchaemal region which conveys the substances of neural origin, such as releasing factors and inhibiting factor(s) of adenohypophysial hormones, from the hypothalamus to the adenohypophysis through the hypophysial portal vessels. We have systematically studied the fine structure of the median eminence to clarify the functional relationship between the adenohypophysis and the hypothalamus. Briefly, there are at least three types of axon endings near the capillaries of the primary plexus of the hypophysial portal vessels: 1) endings containing large electron-dense granules (about $1500 \mathrm{~A}$ in diameter, conceivably paraldehyde-fuchsin(AF)-positive) and small vesicles (about $500 \mathrm{~A}$ ), 2) endings containing small electron-dense granules (about $1000 \mathrm{~A}$, AF-negative, vide infra) and the small vesicles, and 3) endings containing mainly the small vesicles (see Kobayashi 1964; Kobayashi et al., 1965). These axons are intermingled with glial and ependymal processes. In those studeis, synapses have not been detected in the median eminence. Our observations are essentially in agreement with recent observations reported by other investigators (Bern and Nishioka, 1965; Röhlich et al., 1965; Tsuji, 1965; Bern et al., 1966; T. Kobayashi et al., 1966).

Recently, however, we found synaptic contacts in the internal and external layers of the posterior region of the rat median eminence and in those layers of the anterior and posterior divisions of the pigeon median eminence. The synapses exist between the axonal endings

Received for publication June 15, 1967.

* This investigation was supported by a Grant (A-3678) from the U. S. Public Health Service to Dr. Kobayashi and a grant from the Population Council to Dr. Ishii. and cell bodies or processes, which have not clearly been identified whether they are neuronal, glial or ependymal. The pre-synaptic axonal endings contain the small granules $(1000 \mathrm{~A})$ but not the large granules $(1500 \mathrm{~A})$. In these endings, synaptic vesicles aggregate against the thick pre-synaptic membrane. Synaptic clefts exist between the pre-and postsynaptic membranes. The post-synaptic processes possess neither the small granules nor the large granules. Judging from their profiles, the post-synaptic processes seem to be ependymal or glial processes (Figs. 1 and 2). Axo-axonic synapses are also found (Fig. 3, possibly Fig. 4). It is highly probable that the post-synaptic cell bodies are those of glial cells (Figs. 2, 4 and 5), since we noticed in previous studies (Kobayashi and Farner, 1964; Uemura, 1965; Follett et al., 1966) that the nerve cells revealed by histochemistry of acetylcholinesterase were very rare in the median eminence of the rat and birds, whereas there were numerous glial cells.

The small granules in the pre-synaptic processes may be carriers of monoamines. The reasons are as follows: 1) profiles and size of the granules resemble those of the granules identified as noradrenaline carriers in the hypothalamus of the rat (Pellegrino de Iraldi et al., 1963; de Robertis, 1964) and rabbit (Ishii et al., 1965; Matsuoka et al., 1965), 2) the small granules in the axon terminals forming the synapse are very similar in profile and size to small granules in the external layer of the median eminence. These granules in the external layer have also been considered as monoamine carriers, because the distribution of these small granules in the external layer coincides with those of monoamines (Fuxe, 1964; Akmayev and Donáth, 1965; Sano, 1966; Lichtensteiger and Langemann, 1966) and monoamine oxidase (Matsui and Kobayashi, 1965; Follett et al., 1966). Furthermore, the small granules in the 


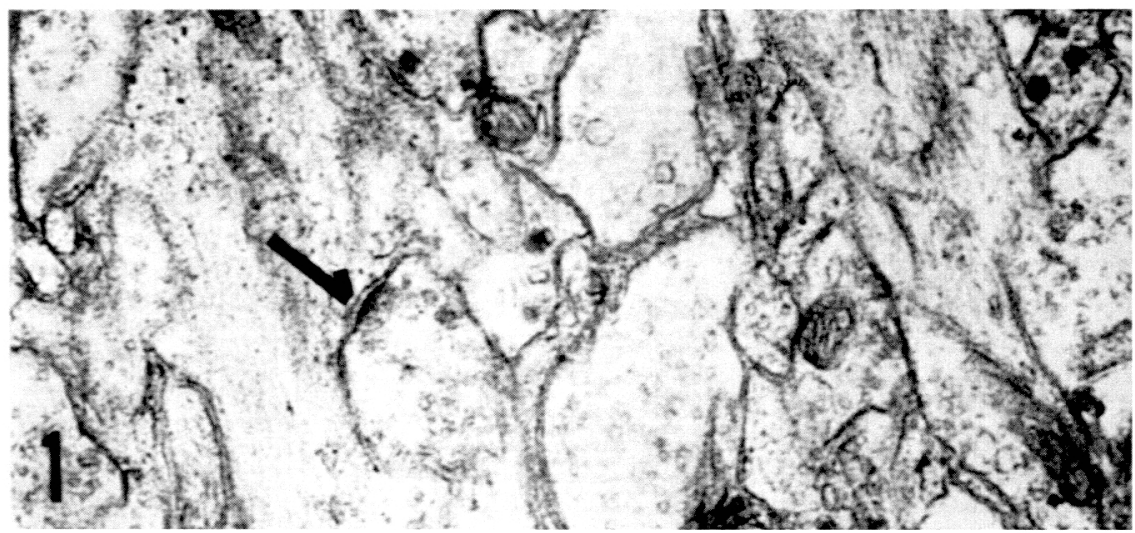

Fig. 1. Synapse in the pigeon posterior median eminence. Post-synaptic side is conceivably an ependymal process. $\times 25,000$

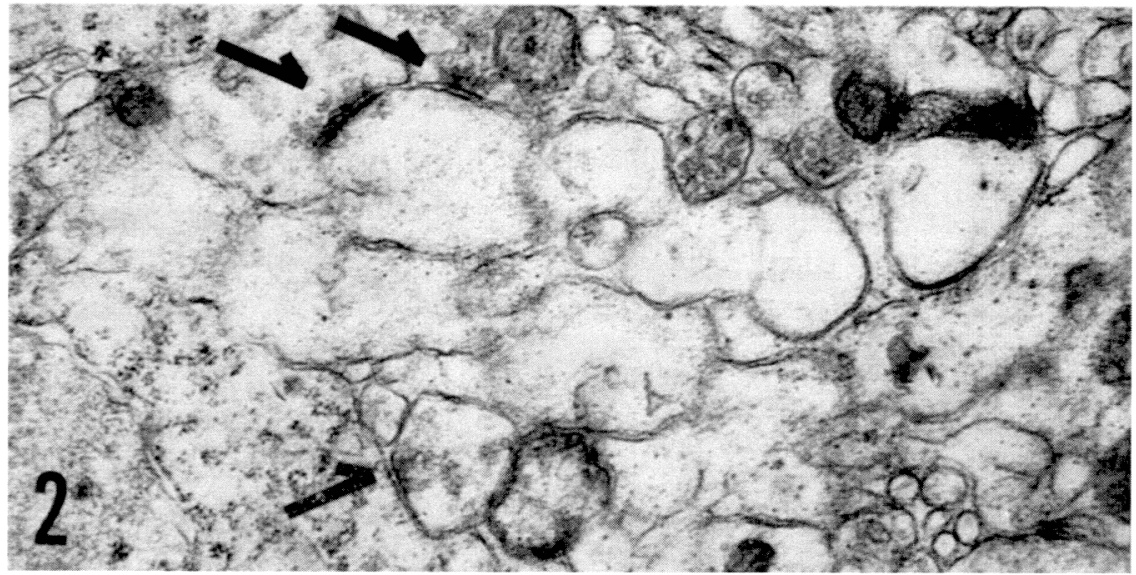

Fig. 2. Synapses in the pigeon posterior median eminence. Post-synaptic sides are a glial cell body (lower arrow) and an ependymal or glial process (upper arrow), respectively. $\times 25,000$

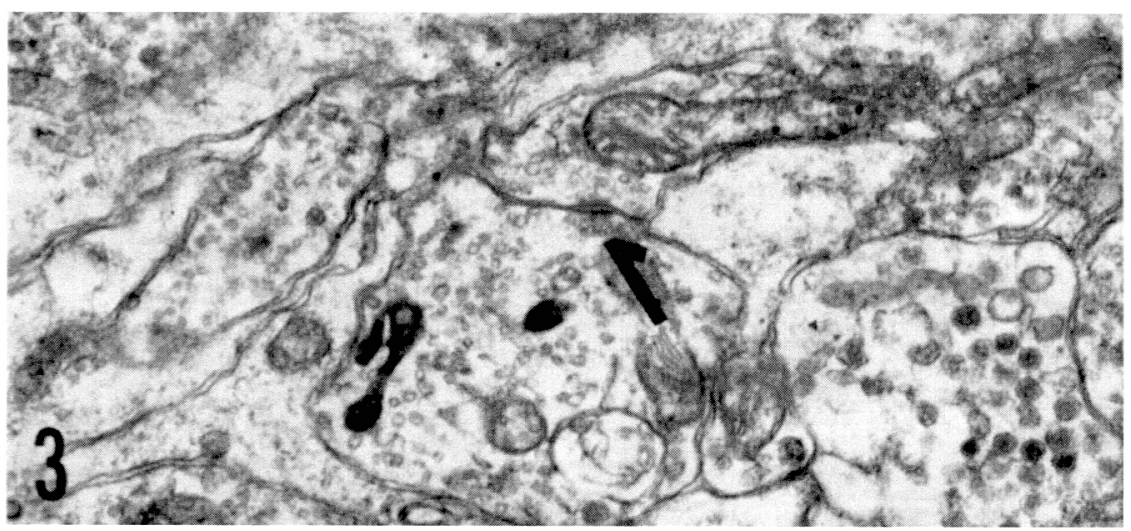

Fig. 3. Axo-axonic synapse in the pigeon anterior median eminence. $\times 25,00 \mathrm{C}$ 


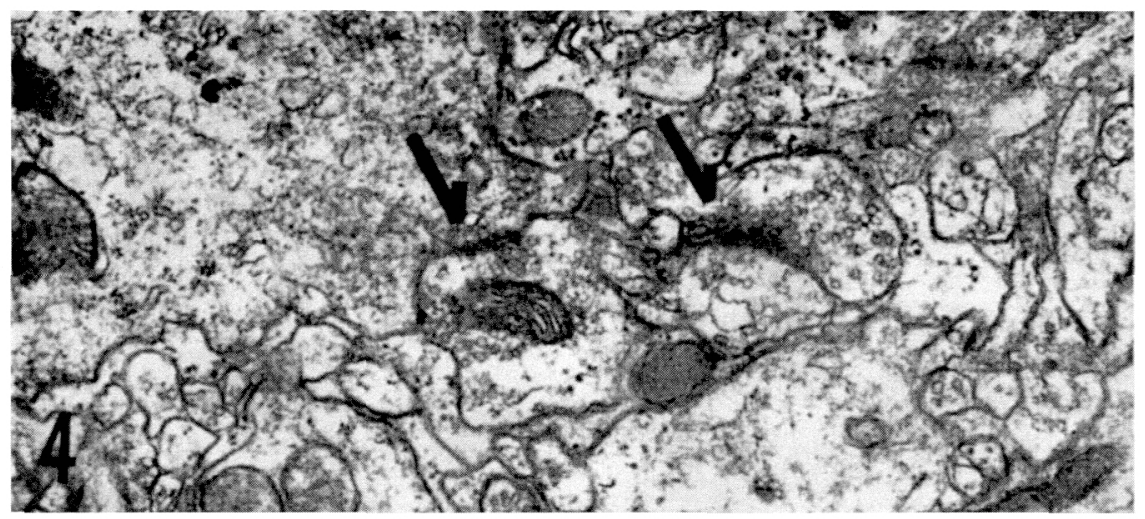

Fig. 4. Synapse between an axon and a glial cell body (left arrow) and axo-axonic synapse (right arrow) in the rat median eminence. $\times 25,000$

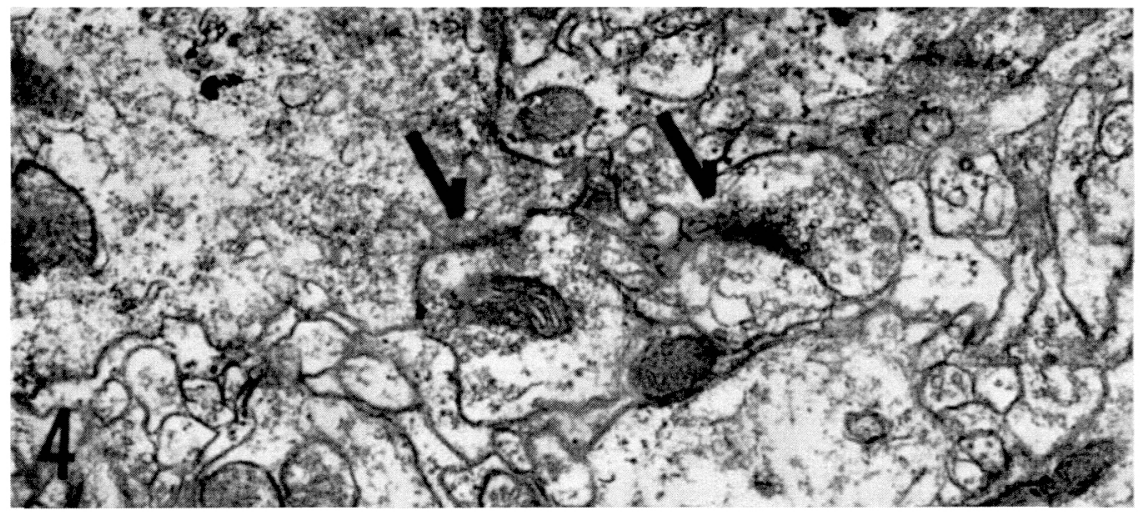

Fig. 5. Synapse between a glial cell body and an axon in the rat median eminence.

$$
\times 25,000
$$

mouse median eminence disappear after the injection of reserpine (Matsui, 1967), which is known one of the releasers of monoamines (Pase, 1958; Shore, 1962). Thus, the small granules in the pre-synaptic axon terminals are conceivably carriers of monoamines. These small granules are not stainable with $\mathrm{AF}$, since the peripheral region of the external layer of the rat and mouse median eminence (Oota, 1963; Kobayashi et al., 1966; Matsui, 1966 b) and the posterior division of the bird median eminence do not take AF (Farner and Oksche, 1962), although the small granules are numerous therein (Matsui, 1966 a and 1967). With regard to the origin of the pre-synaptic axons containing the small granules. it has been suggested that they originate in the arcuate-tuberal nuclei which are of monoaminergic nature and terminate in the posterior region of the median eminence: (Lichtensteiger and Langemann, 1966).

Synaptic contacts between neurosecretory fibers bearing granules (1200 A in diameter) and pituicytes were reported by Knowles and Vollrath (1965) in the pituitary of the eel. They considered that the granules are AFpositive neurosecretory granules (Type A2) produced in the preoptic nucleus. However, there is the possibility that these granules. (Type A2) are identical to the granules of their Type B, which have been thought by them to be carriers of monoamines. The reason is that the granules of Type $B$ in the eel pituitary have an electron-dense core of 
$700 \mathrm{~A}$ in diameter, but their maximum diameter including halo around the core is approximately $1000 \mathrm{~A}$, which is about the same size as that of Type A2 granules. The presence or absence of the core and halo in the secretory granules generally depends on physiological conditions of secretory cells. For instance, in the rat median eminence most of the presumed monoamine granules have no halo but some do (Kobayashi et al., 1966; Matsui, 1966 b), and the pars nervosa of the mouse deprived of drinking water shows the neurosecretory granules with clear halo (Oota and Kobayashi, 1966). Accordingly, we assume that the synaptic contacts found in the eel pituitary may be those between the pituicytes and the axons of monoaminergic nature instead of AF-stainable neurosecretory fibers originated in the preoptic nucleus. An association of neurosecretory fibers and ependymal cells was also reported by Nishioka et al. (1964) in the bird pars nervosa. Here, the granules in the fibers are definitely AF-stainable neurosecretory granules. However, in this case there are no indications of synaptic clefts and thickned synaptic membranes at the site of the association. It is not known, therefore, whether the association is physiologically significant or not.

The secretion of glial cells into the cerebrospinal fluid or the blood vessels in the eel pituitary (Knowles and Vollrath, 1965) and the secretion of ependymal cells lining the rat infundibular recess into the third ventricle have been suggested by others (Lévêque, 1963; Lévêque et al., 1965). In previous papers, we have suggested that the ependymal cells of the median eminence absorb or secrete some substances from or into the cerebrospinal fluid of the third ventricle (Matsui, 1966 a and b). Furthermore, we have suggested the secretion of glial or ependymal cells of the median eminence passes into the portal vessels (Matsui, 1966 $a$ and $b$ ). The monoaminergic synapses found in the median eminence may be involved in regulating their possible absorption from the cerebrospinal fluid and secretion into the capilalries of the primary plexus. If the fibers on the post-synaptic side are neuronal, then it is likely that the synapses found in the median eminence control the secretion of releasing or inhibiting factor(s) of adenohypophysial hormones.

In summary, synapses were found in the posterior region of the rat and pigeon median eminences. The pre-synaptic axon endings contain the small granules (perhaps carriers of monoamines) and the synaptic vesicles. The post-synaptic components seem to be glial cell bodies and glial or ependymal processes. The physiological significance of the synapse found in the median eminence is briefly disscussed.

\section{HIDESHI KOBAYASHI TOKUZO MATSUI \\ Zoological Institute, Faculty of Science, University of Tokyo, Tokyo}

\section{REFERENCES}

Akmayev, I. G. and T. Donáth (1965). Z. mikr. anat. Forsch. 74, 83.

Bern, H. A. and R. S. Nishioka (1965). Proc. Zool. Soc., Culcutta, 18, 107.

Bern, H. A., R. S. Nishioka, L. R. Mewaldt and D. S. Farner (1966). Z. Zellforsch. 69, 198.

De Robertis, E. Histophysiology of Synapses and Neurosecretion. Pergamon Press, Oxford. (1964).

Farner D. S. and A. Oksche (1962). Gen. Comp. Endocrinol. 2, 296.

Follett, B. K., H. Kobayashi and D. S. Farner (1966). Z. Zellforsch. 75, 57.

Fuxe, K. (1964). Z. Zellforsch. 61, 710.

Ishii, S., N. Shimizu, M. Matsuoka and R. Imaizumi (1965). Biochem. Pharmacol. 14, 183.

Knowles, T. and L. Vollrath (1965). Nature 206, 1168.

Kobayashi, H. and D S Farner (1964). Z. Zellforsch 63, 955. 
Kobayashi, H. (1964). Proc. 2nd Intern. Cong. Endocrinol. 1, 570.

Kobayashi, H., T. Hirano and Y. Oota (1965). Arch. d'Anat. Microsc. Morpho. Exper. 54, 277.

Kobayashi, H., Y. Oota, H. Uemura and T. Hirano (1966). Z. Zellforsch. 71, 387.

Kobayashi, T., T. Kobayashi, K. Yamamoto, M. Kaibara, Y. Kameya, M. Kobayashi and Y. Takehashi (1966). Electron Microscopy (Sixth Intern. Cong. Elect. Microsc., Kyoto) 2, 527.

Lévêque, T. F. in Advances in Neuroendrocrinology. ed. A. V. Nalvandov, University of Illinois Press, Urbana. (1963).

Lévêque, T. F., F. Stutinsky, M. E. Stoeckel and A. Porte (1965). Compt. rend. Acad. Sci. Paris, 260, 4621.

Lichtensteiger, W. and H. Langemann (1966). J. Pharmacol. Exptl. Therap. 151, 400.

Matsui, T. (1966 a). J. Fac. Sci., Univ. Tokyo, Sec. IV, 11, 49.

Matsui, T. (1966 b). Ibid. 11, 71.
Matsui, T. (1967). Neuroendocrinol. 2, 99.

Matsui, T. and H. Kobayashi (1965). Z. Zellforsch. 68, 172.

Matsuoka, M., S. Ishii, N. Shimizu and R. Imaizumi (1965). Experientia 21, 121.

Nishioka, R. S., H. A. Bern and L. R. Mewaldt (1964). Gen. Comp. Endocrinol. 4, 304.

Oota, Y. (1963). J. Fac. Sci., Univ. Tokyo, Sec. $I V, 10,155$.

Oota, Y. and H. Kobayashi (1966). Annot. Zool. Japon. 39, 193.

Pase, I. H. (1958). Physiol. Rev. 38, 2877.

Pellegrino de Iraldi, A., H. F. Duggan and E. de Robertis (1963). Anat. Record 143, 521.

Röhlich, P., B. Vigh, I. Teichmann and B. Aros (1965). Acta Biol. Hung. 15, 431.

Sano, Y. (1966). Folia Endocrinol. Japon. 42, 963. (In Japanese)

Shore, P. A. (1962). Pharmacol. Rev. 14, 531.

Tsuji, S. (1965). J. Kyoto Pref. Med. Univ. 74, 446.

Uemura, H. (1965). Annot. Zool. Japon. 38, 79. 